\title{
Investigation on the status of J ohne's disease based on agar gel immunodiffusion, ziehl-neelsen staining and nested PCR approach in two cattle farm
}

\author{
Anand Mohan ${ }^{1}$, Pranabananda Das ${ }^{2}$, Neelam Kushwaha ${ }^{3}$, Kaliaperumal Karthik ${ }^{1}$ and Ankush Kiran Niranjan ${ }^{1}$
}

1. Division of Bacteriology and Mycology, Indian Veterinary Research Institute, Izatnagar - 243122, Uttar Pradesh, India;

2. Division of Biological Products, Indian Veterinary Research Institute, Izatnagar - 243122, Uttar Pradesh, India;

3. Division of Medicine, Indian Veterinary Research Institute, Izatnagar - 243122, Uttar Pradesh, India;

Corresponding author: Anand Mohan, email: dr_rinkuanand@rediffmail.com

Received: 05-06-2013, Revised: 15-07-2013, Accepted: 16-07-2013, Published online: 26-08-2013

doi: 10.14202/vetworld.2013.778-784 How to cite this article: Mohan A, Das P, Kushwaha N, Karthik K and Niranjan AK (2013) Investigation on the status of J ohne's disease based on agar gel immunodiffusion, ziehl-neelsen staining and nested PCR approach in two cattle farm, Veterinary World 6(10): 778-784.

\begin{abstract}
Background and Methods: Paratuberculosis is a chronic disease of ruminant, caused by Mycobacterium avium subsp. paratuberculosis (Map), clinically infected animals produce high level of antibodies in blood and shed detectable amount of Map organisms in feces. Several serological and molecular tests are utilized for detection of antibodies or DNA of the organism in clinical samples. Present study indicates the status of paratuberculosis in two distinct cattle farms with different organizational set-ups viz. organized and unorganized. We used agar gel immunodiffusion (AGID) assay for the detection of antibodies in blood. Ziehl-Neelsen (ZN) staining of fecal smears was done to observe acid-fast bacilli and Nested PCR targeted to IS 900 and $f 57$ sequences, was performed to confirm the pathogen.
\end{abstract}

Results: Sera samples of cattle, from organized farm, did not show any visible precipitating band with AGID assay. However, fecal smears of few cattle (3.57\%) were positive for acid-fast bacilli. When confirmed with nested PCR, only one fecal sample $(0.71 \%)$ was found positive for Map. In case of unorganized farm, a large number of cattle (38.75\%) showed precipitating antibodies with AGID assay and the percentage of fecal smears that showed acid-fast bacilli was $26.62 \%$. Nevertheless, fecal samples containing Map DNA was confirmed in $14.37 \%$ of fecal sample by nested PCR.

Conclusions: An organized farm, with better hygiene and management practices, showed lesser occurrence of paratuberculosis in cattle in comparison to unorganized farm. Not all AGID assays positive cattle might be an efficient shedder of Map and mare detection of acid-fast bacilli in fecal smears did not always indicate the presence of Map organism. Cattle infected with JD were mostly in the age group of six years and above.

Keywords: AGID, f57, Johne's disease, IS900, Nested PCR, Ziehl-Neelsen staining, Mycobacterium avium subspecies paratuberculosis.

\section{I ntroduction}

Johne's disease (JD) or paratuberculosis is chronic, infectious and granulomatous enteritis of ruminants. It is caused by Mycobacterium avium subspecies paratuberculosis. It is considered as a threat to the dairy sector, beef/meat industry and livestock trade [1, 2] in many countries, including India [3]. In spite of exhaustive research on diagnosis, control and prevention, for more than 100 years, it remains as a challenge to the veterinary profession. The primary source of infection in calves is milk, contaminated with feces of diseased animals. Clinical signs of JD are slow progressive wasting condition, diarrhea, which is intermittent at first, becoming progressively more severe and consistent [4].

Various serological methods have been developed for the detection of antibody produced against it. Diagnostic tests, measuring antibody response, lack sensitivity, particularly in early phase of infection and their use have been restricted to the diagnostic confirmation of suspected clinical cases or certifying a

Copyright: The authors. This article is an open access article licensed under the terms of the Creative Commons Attribution License (http://creativecommons.org/licenses/by/2.0) which permits unrestricted use, distribution and reproduction in any medium, provided the work is properly cited. herd as free of infection [3]. Serological assays, including agar gel immunodiffusion (AGID) assay, enzyme-linked immunosorbent assay (ELISA) and complement fixation test have prescribed to detect antibodies against Map in animal sera [5]. Depending on the antigens used, these assays can yield falsepositive results and may not consistently detect infected animals in the early stages of disease [6]. The serological tests currently used in Australia by different diagnostic laboratories in goats comprise the AGID or gel test and the absorbed ELISA [7]. AGID assay has a higher specificity $(>90 \%)$ in animals with clinical signs, but its sensitivity is very low $(\sim 30 \%)$ in early stage of infection [8].

The application of molecular method, for the diagnosis of JD, is under constant development and modification. A number of genes and sequences unique to Map have been identified over the years. The insertion element IS900 has been routinely used to detect the presence of Map in clinical samples. However, sequences related to IS900 like IS902 (Wood pigeon mycobacterium), IS901 (Maa), IS1626 (Maa and $M$. intracellulare $)$ were reported $[9,10,11]$ and hence reduces its specificity. Therefore, a positive IS900 PCR should be confirmed by subsequent nested 
PCR or by a PCR assay targeting another gene. Another sequence named, $f 57$ has been identified and don't have any homology with any known sequences [12,13]. It is recommended to use $f 57$ as complementary with IS 900 in nested PCR format to eliminate false-positive cases [14].

Based on above fact, present study was designed to screen cattle from two distinct farms with entirely different organizational set-up. AGID, Ziehl-Neelsen $(\mathrm{ZN})$ staining and nested PCR approach targeting IS900 and $f 57$ sequences, were used to screen the serum and fecal samples. Standard antigens for AGID were prepared from 8 week old growth culture of Map strain (ATCC 19698) and standard positive control serum was raised in two rabbits against sonicated antigens of Map.

\section{Materials and Methods}

Animal population and sample collection: Cattle from two distinct farms were selected for present study.

A. Unorganized cattle farm: locally, it was called Gaushala or unproductive cattle rehabilitation center. It was situated in the village Barsana, Mathura (Uttar Pradesh). In India aged, unproductive, chronically infected animals were not slaughtered but sent to this type of farms. These animals were maintained by nonprofit, non-government organization until death. A total of 160 sick cattle were selected. These cattle were having history of chronic diarrhea and ill health. Blood and fecal samples were collected from those animals. B. Organized cattle farm: this farm was maintained by GB Pant Agriculture University, Pantnagar (Uttarakhand), for research and educational purposes. Randomly, 140 cattle were selected. Sera was separated from individual blood samples and kept in cold chain. Similarly individual fecal sample, collected directly from the rectum, was kept inside a plastic bag and stored in cold chain. Details of serum and fecal samples collected in respect of age and sex are mentioned in table 1,2 and 3.

Bacterial strain and preparation of antigens: Standard culture of Mycobacterium avium subspecies paratuberculosis (ATCC 19698) was procured from Biological Product Division, Indian Veterinary Research Institute, India. It was maintained in Lowenstein Jenson (LJ) medium containing mycobactin J. For large-scale production of antigen; the culture was grown as a surface pellicle on Watson and Reid synthetic broth containing mycobactin $\mathrm{J}$ and incubated for eight weeks at $37^{\circ} \mathrm{C}$. Bacterial growth was killed by heating at $72^{\circ} \mathrm{C}$ for $2 \mathrm{~h}$ and separated by filtration. The cells were washed thrice with PBS and centrifuged to get cell mass. It was re-suspended in PBS containing $0.2 \mathrm{mM}$ phenyl methyl sulfonyl fluoride and sonicated at 16 amplitude for $45 \mathrm{~min}$ with intermittent breaks. Sonicated preparation was centrifuged at $12000 \mathrm{x}$ g for $1 \mathrm{~h}$ at $4^{\circ} \mathrm{C}$. The supernatant was filtered through 0.22 $\mu \mathrm{m}$ membrane filter. The protein content of the solution was estimated by the bicinchoninic acid method
(Protein estimation kit, GeneiTM). Antigen was diluted with PBS up to protein content to $1 \mathrm{mg} / \mathrm{ml}$, and kept at $20^{\circ} \mathrm{C}$ in different aliquots.

Raising hyperimmune sera: Hyperimmune sera were raised in two healthy adult rabbits (approved by Institute Animal Ethics Committee, No. F.1-53/2004J.D (Res), Dated, 10 ${ }^{\text {th }}$ Jan. 2012) against Map as per the methods described by Castelnuovo et al. [15] with suitable modifications. Briefly, antigen consisting of an emulsion of $100 \mathrm{mg}$ of whole cells, $5 \mathrm{mg}$ of sonicated antigen and $2 \mathrm{ml}$ of sonicated sediment was mixed with an equal amount of Freund's incomplete adjuvant (Difco). Each of two rabbits was inoculated with $0.5 \mathrm{ml}$ of above emulsion subcutaneously at weekly intervals for 6 weeks. Antibody titer was monitored by AGID assay after $5^{\text {th }}$ injection. Rabbits were bled one week after the last injection, and serum was stored at $-20^{\circ} \mathrm{C}$.

Agar gel immunodiffusion assay: One-percent agarose gel was prepared in PBS ( $\mathrm{pH}$ 7.4) containing sodium azide $(0.02 \%, \mathrm{w} / \mathrm{v})$. Gel was cast into sterile plastic petriplates and allowed to solidify at $4^{\circ} \mathrm{C}$ for $1 \mathrm{~h}$ in the humid chamber. Wells of $3 \mathrm{~mm}$ diameter were punched out in a hexagonal pattern with six peripheral wells for sera and one centre well for the antigen at equi-distance of $5 \mathrm{~mm}$ between them. The central well was filled with sonicated antigen with optimum concentration (1 $\mathrm{mg} / \mathrm{ml})$. The test sera was charged in duplicate in six peripheral wells and incubated at $4{ }^{\circ} \mathrm{C}$ overnight in the humid chamber along with positive control. Gels were examined after 24 and $48 \mathrm{~h}$ and in suspected cases after $72 \mathrm{~h}$. White precipitation line between antigen and sera wells was taken as positive where as an absence of a precipitation line was recorded as negative.

Processing of fecal samples: Fecal samples were decontaminated to remove contaminant microorganism as the procedure mentioned OIE terrestrial manual [1]. Hexadecylpyridium chloride (HPC) at final concentration of $0.75 \%(\mathrm{~W} / \mathrm{V})$ was used for decontamination of fecal samples. Briefly, $1 \mathrm{~g}$ feces and $20 \mathrm{ml}$ of sterile distilled water was vortex in $50 \mathrm{ml}$ tube for half an hour to make a homogenous mixture. The larger particles were allowed to settle for $30 \mathrm{~min}$ at room temperature. The uppermost $5 \mathrm{ml}$ of faces suspension was transferred to a $50 \mathrm{ml}$ tube containing $20 \mathrm{ml}$ of $0.9 \%$ HPC and tubes were inverted several times to assured uniform distribution and allowed to stand undisturbed for $18 \mathrm{~h}$ at room temperature. Undisturbed sediments were used for $\mathrm{ZN}$ staining.

Ziehl-Neelsen staining: Smears were prepared from $100 \mu \mathrm{l}$ sediment of decontaminated fecal samples and air dried. It was heat fixed by passing slide 4-5 times over flame and stained with strong solution of Carbol fuchsin with the help of heat for five minutes without boiling. Thereafter, smear was decolorized with $3 \%$ acid alcohol and subsequently counter stained with $5 \%$ malachite green. Slides were screened in an oil 
Table-1. Number of JD positive case from unorganized cattle farm and organized dairy farm with respect to age and sex. AGID assay was used to screen sera samples from both farms. Figure in parentheses indicate percentage, $\mathrm{P}=$ No. of positive samples, $\mathrm{T}=$ Samples tested.

\begin{tabular}{|c|c|c|c|c|}
\hline \multirow[t]{3}{*}{ Age } & \multicolumn{4}{|c|}{ Agar Gel Immunodiffusion assay } \\
\hline & \multicolumn{2}{|c|}{ Unorganized cattle farm } & \multicolumn{2}{|c|}{ Organized dairy farm } \\
\hline & $\mathbf{P}(\%)$ & $\mathbf{T}$ & $\mathbf{P}(\%)$ & $\mathbf{T}$ \\
\hline \multicolumn{5}{|l|}{ Male } \\
\hline $0-<3$ yrs & - & 4 & - & - \\
\hline $3-<6$ yrs & - & - & - & - \\
\hline$\geq 6 \mathrm{yrs}$ & - & 1 & - & - \\
\hline Sub-total & - & 5 & - & - \\
\hline \multicolumn{5}{|l|}{ Female } \\
\hline $0-<3$ yrs & $4(20.00)$ & 20 & - & 16 \\
\hline $3-<6$ yrs & $10(45.45)$ & 22 & - & 59 \\
\hline$\geq 6 \mathrm{yrs}$ & 48 (42.48) & 113 & - & 65 \\
\hline Sub-total & $62(40.00)$ & 155 & - & 140 \\
\hline Grand Total & $62(38.75)$ & 160 & - & 140 \\
\hline
\end{tabular}

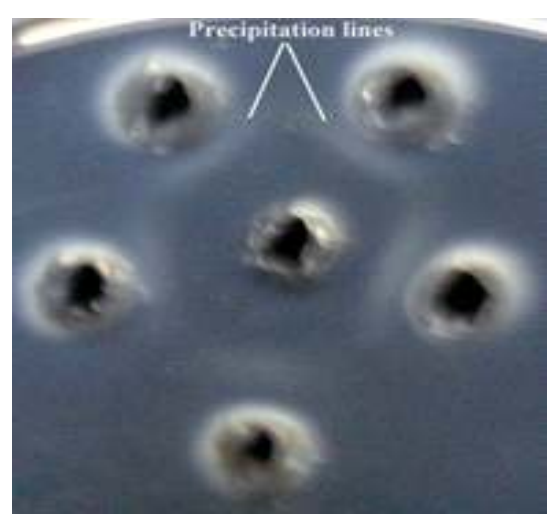

Figure-1. AGID assay, a portion of petri plate showing white precipitation line between cytoplasmic antigens of Map and antibodies from cattle sera. immersion field of a light microscope. Results were interpreted as acid-fast positive if minimum four field in oil immersion had at least five bacilli per field, as morphology seen in positive slide prepared in parallel with samples with Map strain (ATCC 19698), otherwise it was considered as acid-fast negative.

Extraction of genomic DNA from fecal samples: Approximately, $200 \mathrm{mg}$ fecal samples was used to isolate genomic DNA by using QIAamp Stool DNA kit (Qiagen ${ }^{\circledR}$ ) according to manufacturer's instruction. Extracted DNA were stored at $-20^{\circ} \mathrm{C}$ for further use.

Nested polymerase chain reaction: Oligonucleotides used were taken from published literature [14]. Amplification of both sequences was based on the nested PCR approach; PCR product of first run was used as the template for the $2^{\text {nd }}$ amplification. Briefly, for 1st run; primers IS900 F (5'-GGGTTGATC TGG ACAATGACGGTTA-3') and IS900 R (5'-AGC GCG GCACGGCTCTTGTT-3') were used for amplification of IS900, whereas, primers, F57 F (5'-CCTGTC TAA TTCGATCACGGACTAGA-3') and F57 R (5'-TCA GCTATTGGTGTACCGAATGT-3') for amplification of f57. In $2^{\text {nd }}$ amplification, IS900 FN (5'-GGAG GT GGTTGTGGCACAACCTGT-3') and IS900 RN (5'CGATCAGCCACCAGATCGGAA-3') were used to anneal the amplified product of IS 900 from first run. Similarly, F57 F and F57 RN (5'-TGGTGT ACC GAATGTTGTTGTCAC-3') were used to anneal the amplified product of $f 57$ amplification of first run.

PCR reaction mixtures for $1^{\text {st }}$ and $2^{\text {nd }}$ amplification of IS 900 and $f 57$ were made in total volume of $25 \mu \mathrm{l}$. Final concentrations of different constituents in reaction mixture were made respectively as, tris- $\mathrm{Cl}(\mathrm{pH}$ 9); 10 mM, KCl; 50 mM, MgCl2; 1.6 mM, dNTP mix; $800 \mu \mathrm{M}$ total; primers; $0.8 \mu \mathrm{M}$ each; Red Taq polymerase; $0.5 \mathrm{U}$, triton-X100; $0.01 \%$ and DNA templates; 10-20 ng. For positive control, DNA isolated from standard Map strain (ATCC 19698) were used whereas, nuclease-free water in negative control. Amplification of both sequences were performed in thermocyclar (Biometra) with amplification conditions respectively in sequence as, initial denaturation $\left(94^{\circ} \mathrm{C}\right)$ for $4 \mathrm{~min}$; followed by 40 cycles (25 cycles for 2 nd run) of denaturation $\left(94^{\circ} \mathrm{C}\right)$, annealing $\left(68^{\circ} \mathrm{C}\right)$ and extension $\left(72^{\circ} \mathrm{C}\right)$, each for 45 $\mathrm{sec}$; and at last, final extension $\left(72^{\circ} \mathrm{C}\right)$ for $10 \mathrm{~min}$ was given.

PCR products were analyzed by electrophoresis in $1 \mathrm{X}$ Tris-acetate EDTA (TAE) for $2 \mathrm{~h}$ at $50 \mathrm{~V}$. PCR products along with DNA marker were loaded in $2 \%$ (w/v) agarose gel, made in $1 \mathrm{X}$ TAE containing 0.5 $\mu \mathrm{g} / \mathrm{ml}(\mathrm{w} / \mathrm{v}$ ) ethidium bromide. Separation of DNA was visualized by ultraviolet at $260 \mathrm{~nm}$.

\section{Results}

Agar gel immunodiffusion assay: Samples from two cattle farms were screened for JD using cytoplasmic antigens, obtained after sonication of standard Map strain (ATCC 19698) along with sera raised in rabbit against sonicated antigens of Map as positive control. Sera samples of cattle, from organized farm, did not show any visible precipitating band in AGID assay. However, cattle from unorganized cattle farm (38.75\%) were markedly infected with this disease. Particularly, in female animals, $40.00 \%$ of the total screened samples found to be infected with this disease (Table-1, Figure-1). Most of the positive cases in female animals were from the age group $\geq 6$ yrs (48 out of 113), followed by 3 to $<6$ yrs ( 10 out of 22 ) and $<3$ yrs ( 4 out of 20), respectively. Infection level in male animals from organized farm were unable to trace because, number of sera samples included in the study was too less to detect even a single case of JD.

Ziehl-Neelsen staining: Similar to AGID assay, feces from male animals from organized and unorganized cattle farms were failed to demonstrate, even a single animal shedding acid fast bacilli (AFB). As mentioned in previous section, lesser numbers of sera samples included in the present study reduced the chances of detection of animals shedding AFB. However, in female animals, $26.45 \%$ and $3.57 \%$ fecal samples respectively, from unorganized cattle farm and organized dairy farm, were shedding AFB (Table-2, Figure-2). Female animals in the age group of $\geq 6 \mathrm{yrs}$ (34 out of 113) shed maximum number of AFB, 
Table-2. Number of JD positive case from unorganized cattle farm and organized dairy farm with respect to age and sex. ZN staining was used to screen the fecal smears, prepared from decontaminated fecal samples (with $0.75 \% \mathrm{HPC}$ ). Figure in parentheses indicate percentage. $\mathrm{P}=$ No. of positive samples, $\mathrm{T}=$ Samples tested.

\begin{tabular}{|c|c|c|c|c|}
\hline \multirow[t]{3}{*}{ Age } & \multicolumn{4}{|c|}{ Ziehl-Neelsen Staining of fecal samples } \\
\hline & \multicolumn{2}{|c|}{ Unorganized cattle farm } & \multicolumn{2}{|c|}{ Organized dairy farm } \\
\hline & $\mathbf{P}(\%)$ & $\mathbf{T}$ & $\mathbf{P}(\%)$ & $\mathbf{T}$ \\
\hline \multicolumn{5}{|l|}{ Male } \\
\hline $0-<3$ yrs & - & 4 & - & - \\
\hline $3-<6$ yrs & - & - & - & - \\
\hline$\geq 6$ yrs & - & 1 & - & - \\
\hline $\begin{array}{l}\text { Sub-total } \\
\text { Female }\end{array}$ & - & 5 & - & - \\
\hline $0-<3$ yrs & $3(15.00)$ & 20 & - & 16 \\
\hline $3-<6$ yrs & $4(18.18)$ & 22 & - & 59 \\
\hline$\geq 6 \mathrm{yrs}$ & $34(30.09)$ & 113 & $5(7.69)$ & 65 \\
\hline Sub-total & $41(26.45)$ & 155 & $5(3.57)$ & 140 \\
\hline Grand Total & 41 (25.62) & 160 & 5 (3.57) & 140 \\
\hline
\end{tabular}

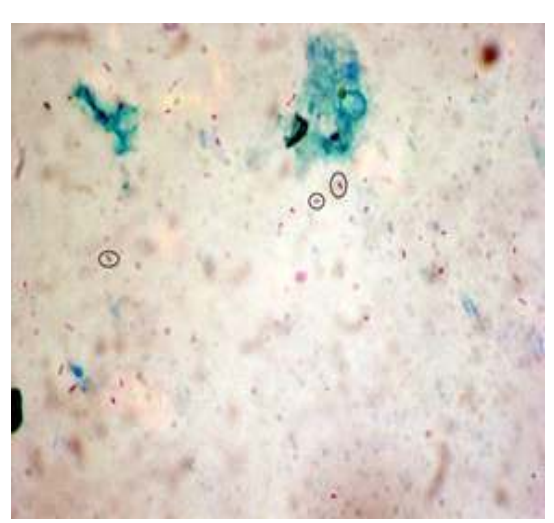

Figure-2. ZN staining of decontaminated fecal samples (with $0.75 \%$ HPC) showing red color AFB (Encircled with black solid line).

Table-3. Number of JD positive case from unorganized cattle farm and organized dairy farm with respect to age and sex. Nested PCR approach, targeted to both IS900 and f57 sequences, was used to screen the fecal samples. Figure in parentheses indicate percentage, $P=$ No. of positive samples, $\mathrm{T}=$ Samples tested.

\begin{tabular}{llllc}
\hline Age & \multicolumn{4}{c}{ Nested PCR for both IS900 and f57 } \\
\cline { 2 - 5 } & \multicolumn{2}{l}{ Unorganized cattle farm } & \multicolumn{2}{l}{ Organized dairy farm } \\
& $\mathbf{P}(\%)$ & $\mathbf{T}$ & P (\%) & T \\
\hline Male & $1(25.00)$ & 4 & - & - \\
$0-<3$ yrs & - & - & - & - \\
$3-<6$ yrs & - & 1 & - & - \\
$\geq 6$ yrs & $1(20.00)$ & 5 & - & - \\
Sub-total & $3(15.00)$ & 20 & - & 16 \\
Female & $4(18.18)$ & 22 & - & 59 \\
$0-<3$ yrs & $15(13.27)$ & 113 & $1(1.54)$ & 65 \\
$3-<6$ yrs & $22(14.19)$ & 155 & $1(0.71)$ & 140 \\
$\geq 6$ yrs & $23(14.37)$ & 160 & $1(0.71)$ & 140 \\
Sub-total & & & & \\
Grand Total & & & & \\
\hline
\end{tabular}

followed by 3 to $<6$ yrs ( 4 out of 22$)$ and $<3$ yrs ( 3 out of 20), respectively in unorganized cattle farm. Although, only female animals from the age group $\geq 6$ yrs (5 out of 65) in organized dairy farm were established to shed AFB.

Nested PCR approach: Samples along with positive controls given amplicons of $572 \mathrm{bp}\left(1^{\text {st }}\right.$ run, IS900; Figure 3a), 452bp ( $2^{\text {nd }}$ run, IS 900 ; Figure $\left.3 b\right), 432 b p\left(1^{\text {st }}\right.$ run, f57; Figure 3c) and 424bp ( $2^{\text {nd }}$ run, f57; Figure 3d) taken as positive for Map, provided that, no amplicons in negative controls. Overall, $14.37 \%$ and $0.71 \%$ animals respectively, in unorganized cattle farm and organized dairy farm were diagnosed JD positive (Table-3). Although, $14.14 \%$ and $0.71 \%$ females, respectively in unorganized cattle farm and organized dairy farm were harbored Map bacilli. In unorganized cattle farm, maximum number of female animals in the age group $\geq 6$ yrs (15 out of 113) were positive, followed by 3 to $<6$ yrs ( 4 out of 22 ) and $<3$ yrs ( 3 out of 20) respectively. Whereas, in case of organized dairy farm, only one female of age group of $\geq 6$ yrs was positive for JD. Similarly, only one male animal of less than 3 yrs was diagnosed as JD positive from unorganized cattle farm.

\section{Discussion}

In India, JD was first reported in 1912 from Lahore (undivided India) [16]. Since, a large number of cases have been reported in different cattle farms with significant economic losses. During 1930s, large-scale surveys carried out in Assam [17], revealed high prevalence $(25-50 \%)$ of johnin reactors at all government cattle farms. Most of the earlier prevalence studies were not statistically viable. Standard statistical procedure was not followed for sampling and herd selection. Even though, samples collected from the animals which had clinical sign suggesting JD. Therefore, in terms of proportion, diagnosed cases secured higher prevalence than the endemic level.

Till today, countrywide survey of Map infection has not been undertaken so far, but investigations by different workers $[18,19,20]$ indicated, it is endemic in domestic livestock. In the present study, 38.75\% animals in unorganized cattle farm were diagnosed JD positive by AGID. In same groups, Nested PCR confirmed $14.37 \%$ positive animals, whereas $25.62 \%$ animals shed AFB. Kaur et al. [21] identified even higher number of animals positive for JD in similar kind of investigation. She detected $71 \%$ animals 


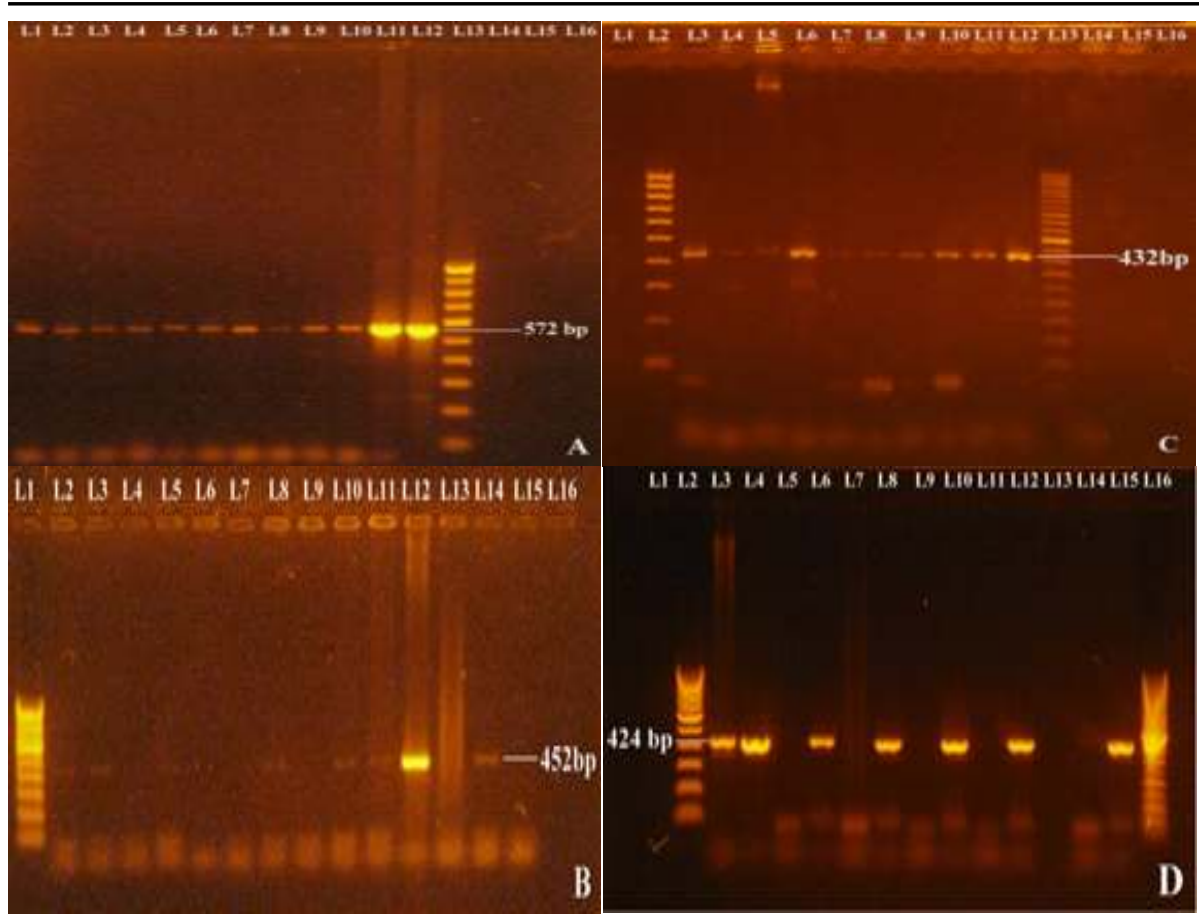

Figure-3. Map specific amplicons from fecal samples by nested PCR. (A): First amplification, 572bp (IS900); L1 to L10 - DNAs belongs to samples, L11 and L12 Positive control, L13 - 100bp marker, L14 - Negative control, L15 and L16 - Blanks. (B): Second amplification, $452 \mathrm{bp}$ (IS900); L1 - 100bp marker, L2 and L14 - amplicons belongs to PCR products correspond to positive controls of $1^{\text {st }}$ amplification, L3 to L13 - amplicons belong to PCR products correspond to samples of $1^{\text {st }}$ amplification, L15 - amplicon belong to PCR product correspond to negative control of $1^{\text {st }}$ amplification, L16 - Blank. (C): First amplification, 432bp (f57); L1 - Blank, L2 - 100bp marker, L3 to L11 - DNAs belongs to samples, L12 Positive control, L13 - 50bp marker, L14 Negative control, L15 and L16 Blanks. (D): Second amplification, 424bp (f57); L1 - Blank, L2 - 100bp marker, L3 and L15 - amplicons belongs to PCR products correspond to positive control of $1^{\text {st }}$ amplification, L4 to L13 amplicons belongs PCR products correspond to samples of $1^{\text {st }}$ amplification, L14 - amplicon belong to PCR product correspond to negative control of $1^{\text {st }}$ amplification, L16 - 50bp marker. harbored AFB and 55\% positive in IS900 PCR in groups of animals showed clinical signs suggested to JD. In same region (Mathura, India), Singh et al. [22], by using indigenous ELISA, diagnosed $25.8 \%$ animals infected. In domestic animals, different workers have estimated 20-30\% animals infected with JD [22, 23, 24, $25]$. In contrast, some authors detected comparatively lower prevalence in different animal farms [26, 27].

Maximum numbers of animals in the age group $\geq$ 6 yrs shed AFB, Map and produced detectable humoral immune response. Long incubation period and complex interaction of bacilli with immune system delay the shedding of bacilli in feces [28]. Therefore, diagnostic used to detect bacilli in feces and humoral responses in blood gives more positive results in older animals or in clinical stage of disease. Cell-mediate immune response predominate $[29,30,31]$ in the initial stage of infection. If animal fails to resist the multiplication of bacilli, it switches its immune response toward humoral [32], which are detectable by all commonly implied serological tests. Vazquez et al. [33] make out an observation; serologically positive case, infected early in life will produce a noticeable humoral response in around 3-4 yrs of age. All these accounts for high level of infection diagnosed in older animals (In present case, it was $\geq 6$ yrs age).

Among the tests used, AGID performed well in unorganized cattle farm. However, in organized dairy farm, same test didn't recognize even a single positive animal. Although, 3.57\% animals shed AFB and $0.71 \%$ are Map positive (nested PCR) in organized dairy farm. Mere detection of AFB in feces will not warrant Map; it may be other common inhabitants of intestine. Standard managemental husbandry practices followed in organized dairy farm limit JD to undetectable level. It has been pointed out by different workers, important management practices influence the JD occurrence in a farm are; overall cleanliness, manure disposal, newborn-calf care, separation of calves from infected ones, etc. [34, 35, 36, 37].

Complex organic matters, toxic components like phenol in feces make DNA isolation difficult. Some of them have been identified as polymerase inhibitors [38] used in later steps. Shedding of Map bacilli in feces are erroneous except, the clinical and advance stage of disease [39]. Therefore, PCR amplification of DNA isolated has given lower efficacy. Not only PCR but AGID also detected clinical or advance stage of disease. Noticeable humoral responses are generated in animal at later stage of infection [31]. So it may be predicted that the level of infection both in organized and unorganized cattle farm may higher as diagnosed by PCR or AGID.

\section{Conclusions}

It was evidenced that an organized farm, with better hygiene and management practices, showed lesser occurrence of JD in cattle in comparison to unorganized farm. In unorganized farm, a large number of cattle were sero-positive with AGID assay. However, all the sero-positive cattle did not shad AFB when examined by ZN stain. Again, the cattle smears which were positive for AFB did not always contain DNA of Map organism. This indicated that, all seropositive cattle might not be the efficient shedder of Map and mare detection of AFB in fecal smears did not always indicate the presence of Map organism. Cattle infected with JD were mostly in the age group of six years and above.

\section{Authors' contributions}

AM and PD planned and designed the study. AM, NK and AKN collected the samples from farms. AM and PD maintained and culture the Map as surface pellicle 
on broth, AM and KK produced the sonicated antigens and raised hyperimmune sera. AM performed the laboratory works. AM and NK prepared the manuscript. All authors revised and approved the final manuscript.

\section{Acknowledgements}

Authors are thankful to Dr. Ranbir Singh, Senior Scientist, Animal Genetics Division, Indian Veterinary Research Institute, Izatnagar-243 122 for helping in sample collection. Authors are thankful to University Grant Commission/Indian Council of Agricultural Research, New Delhi for providing fund (No. 2-65/98 (SA-I), dated $12^{\text {th }}$ July 2012.) to carry out this work.

\section{Competing interests}

The authors declare that they have no competing interests.

\section{References}

1. Richardson, E.K.B. and More, S.J. (2009) Direct and indirect effects of Johne's disease on farm and animal productivity in an Irish dairy herd, Ir. Vet. J., 62(8): 526-532.

2. Lombard, J.E. (2011) Epidemiology and economics of paratuberculosis, Vet. Clin. Food Anim. Pract., 27(3): 525535.

3. Tripathi, B.N., Munjal, S.K. and Paliwal, O.P. (2002) An overview of paratuberculosis (Johne's disease) in animals, Indian J. Vet. Pathol., 26(1-2): 1-10.

4. OIE (2012) Manual of diagnostic tests and vaccines for terrestrial animals, Vol.1, Chapter 2.1.11.

5. Gilardoni, L.R., Paolicchi, F.A., Mundo, S.L. (2012) Bovine paratuberculosis: a review of the advantages and disadvantages of different diagnostic tests, Rev. Argent. Microbiol., 44(3): 201-215.

6. Diéguez, F.J., González, A.M., Menéndez, S., Vilar, M.J., Sanjuán, M.L., Yus, E. and Arnaiz, I. (2009) Evaluation of four commercial serum ELISAs for detection of Mycobacterium avium subsp. paratuberculosis infection in dairy cows, Vet. J., 180(2): 231-235.

7. Whittington, R.J., Eamens, G.J. and Cousins, D.V. (2003) Specificity of absorbed ELISA and agar gel immunodiffusion tests for paratuberculosis in goats with observations about use of these tests in infected goats, Aust. Vet. J., 81(1-2): 71-75.

8. Hermel, S.R. (1998) Testing for Johne's, Angus Journal, 3: 194-202.

9. Cousins, D.V., Whittington, R., Marsh, I., Masters, A., Evans, R.J. and Kluver, P. (1999) Mycobacteria distinct from Mycobacterium avium subsp. paratuberculosis isolated from the faeces of ruminants possess IS900 like sequences detectable by IS 900 polymerase chain reaction: implications for diagnosis, Mol. Cell. Probe, 13(6): 431-442.

10. Puyang, X., Lee, K., Pawlichuk, C. and Kunimoto, D.Y. (1999) IS1626, a new IS900 related Mycobacterium avium insertion sequence, Microbiol., 145(11):3163-3168.

11. Englund, S., Bölske, G. and Johansson, K.E. (2002) An IS900 like sequence found in a Mycobacterium sp. other than Mycobacterium avium subspecies paratuberculosis, FEMS Microbiol.Lett., 209(2): 267-271.

12. Poupart, P., Coene, M., Van Heuverswijn, H. and Cocito, C. (1993) Preparation of a specific RNA probe for detection of Mycobacterium paratuberculosis and diagnosis of Johne's disease, J. Clin. Microbiol., 31(6): 1601-1605.

13. Coetsier, C., Vannuffel, P., Blondeel, N., Denef, J.F., Cocito, C. and Gala, J.L. (2000) Duplex PCR for differential identification of Mycobacterium bovis, M. avium, and $M$. avium subsp. paratuberculosis in formalin-fixed paraffinembedded tissue from cattle, J. Clin. Microbiol., 38(8): 3048-3054.
14. Vansnick, E., de Rijk, P., Vercammen, F., Geysen, D., Rigouts, L. Portaels, F. (2004) Newly developed primers for the detection of Mycobacterium avium subspecies paratuberculosis, Vet. Microbiol., 100(3-4): 197-204.

15. Castelnuovo, G., Yamanaka, S., Zeppis, M. and Dotti, E. (1969) The protein components of M. phlei fractionation procedures, Tubercle, 50(2): 194-202.

16. Twort, F. and Ingram, G.L.Y. (1912) A method for isolating and cultivating Mycobacterium enteritidis chronicae pseudotuberculosis bovis, johne and some experiments on the preparation of a diagnostic vaccine for pseudotuberculosis enteritis of bovines, Proc. R. Soc. Lond. B., 84: 517542.

17. Pande, P.G. (1940). Paratuberculosis (John's disease) of cattle in Assam, Indian J. Vet. Sci., 10: 40-62.

18. Kumar, P., Singh, S.V., Bhatiya, A.K., Sevilla, I. Singh, A.V., Whittington, R.J., Juste, R.A. Gupta, V.K., Singh, P.K. Sohal, J.S. and Vihan, V.S. (2007) Juvenile Capri-Paratuberculosis (JCP) in India: Incidence and characterization by six diagnostic tests, Small Rum. Res., 73(1-3): 45-53.

19. Sharma, G., Singh, S.V., Sevilla, I., Singh, A.V., Whittington, R.J., Juste, R.A., Kumar, S., Gupta, V.K., Singh, P.K., Sohal, J.S. and Vihan, V.S. (2008) Evaluation of indigenous milk ELISA with m-culture and $\mathrm{m}$-PCR for the diagnosis of Bovine Johne's disease (BJD) in lactating Indian dairy cattle, Res. Vet. Sci., 84(1): 30-37.

20. Singh, P.K., Singh, S.V., Singh, A.V. and Sohal, J.S. (2008) Screening of tissues serum by culture, PCR and ELISA for the detection of Mycobacterium avium subspecies paratuberculosis from cases of clinical ovine Johne's disease in farmer's flocks, Indian J. Anim. Sci., 78(10): 1052-1056.

21. Kaur, P., Filia, G., Singh, S.V., Patil, P.K., Ravi Kumar, G.V.P.P.S. and Sandhu, K.S. (2011) Molecular epidemiology of Mycobacterium avium subspecies paratuberculosis: IS900 PCR identification and IS1311 polymorphism analysis from ruminants in the Punjab region of India, Comp. Immunol. Microbiol. Infect. Dis., 34(2): 163-169.

22. Singh, A.V., Singh, S.V., Singh, P.K., Sohal, J.S. and Mahour, K. (2010) Sero-surveillance of Mycobacterium avium Subspecies Paratuberculosis Infection in domestic livestock in North India using indigenous absorbed ELISA test, $J$. Adv. Lab. Res. Bio., 1(1): 976-761.

23. Mishra, P., Singh, S.V., Bhatiya, A.K., Singh, P.K., Singh, A.V. and Sohal, J.S., (2007) Real time estimates of prevalence of Bovine Johne's disease in dairy cattle herds in Mathura region of North India using fecal culture and indigenous ELISA kit and characterization of Mycobacterium avium subspecies paratuberculosis by IS900 PCR, paper presented to the Proceedings of $9^{\text {th }}$ International Colloquium on Paratuberculosis, Tsukuba, Japan, October 28 - November 2.

24. Tripathi, B.N., Sonawane, G.G., Munjal, S.K., Bind, R.B., Gradinaru, D., Dubey, S.C., Tripathi, S., Mondal, D., Paliwal, O.P. and Singh, N. (2007) Seroprevalence of paratuberculosis in selected population of ruminants in India, paper presented to the Proceedings of $9^{\text {th }}$ International Colloquium on Paratuberculosis, Tsukuba, Japan, October 28 - November. 2.

25. Singh, S.V., Singh, A.V., Singh, P.K., Sohal, J.S. and Sharma, M.C. (2009) Sero-prevalence of Mycobacterium avium subspecies paratuberculosis infection in low productive domestic ruminants with clinical and sub-clinical Johne's disease in India, paper presented to the Proceedings of $10^{\text {th }}$ International Colloquium on Paratuberculosis, Minneapolia, Mimnesota, August 9-11.

26. Mohan, M.S., Duraisamy, P., Praveena, P.E., Sivakumar, P., Tripathi, B.N. and Singh, N. (2009) Prevalence of paratuberculosis in cattle and buffaloes, Indian Vet. J., 86(1): 4-6.

27. Kumar, V., Gunaseelan, L., Sekar, M. and Ronald, B.S.M. (2012) Prevalence of Cattle Paratuberculosis in Farmer's Field of Tamilnadu, State, India. paper presented to the 
Proceedings of $11^{\text {th }}$ International Colloquium on Paratuberculosis, Sydney, Australia, February 5-10.

28. Sweeney, R.W. (2011) Pathogenesis of paratuberculosis, Vet. Clin. Food Anim. Pract., 27(3): 537-546.

29. Mackintosh, C.G., Clark, R.G., Tolentino, B., de Lisle, G.W., Liggett, S. and Grif? n, J.F.T. (2011) Immunological and pathological responses of red deer resistant or susceptible genotypes, to experimental challenge with Mycobacterium avium subsp. paratuberculosis, Vet. Immunol. Immunopathol., 143(1-2): 131-142.

30. Arsenault, R.J., Li, Y., Bell, K., Doig, K., Potter, A., Griebel, P.J., Kusalik, A. and Napper, S. (2012) Mycobacterium avium subsp. paratuberculosis Inhibits Gamma InterferonInduced Signaling in Bovine Monocytes: Insights into the Cellular Mechanisms of Johne's disease, Infect. Immun., 80(9): 3039-3048.

31. Charavaryamath, C., Gonzalez-Cano, P., Fries, P., Gomis, S., Doig, K., Scruten, E., Potter, A., Napper, S. and Griebel, P.J. (2013) Host Responses to Persistent Mycobacterium avium subspecies paratuberculosis Infection in Surgically Isolated Bovine Ileal Segments, Clin. Vaccine Immunol., 20(2):156165.

32. Begg, D.J., de Silva, K., Carter, N., Plain, K.M., Purdie, A. and Whittington, R.J. (2011) Does a Th1 over Th2 dominancy really exist in the early stages of Mycobacterium avium subspecies paratuberculosis infections ? Immunobiol., 216 (7): 840-846.

33. Vazquez, P., Molina, E., Alonso-Hearn, M., Geijo, M.V., Sevilla, I.A., Estonba, A., Ruiz, O., Garrido, J.M. and Juste, R.A. (2009) Age structure of Mycobacterium avium subsp. paratuberculosis infection in culled Friesian cattle,
Proceedings of $10^{\text {th }}$ International Colloquium on Paratuberculosis, Minneapolis Minnesota, August 9-14,185.

34. Collins, M.T., Sockett, D.C., Googdger, W.J., Conrad, T.A., Thomas, C.B. and Carr, D.J. (1994) Herd prevalence and geographic distribution of, and risk factors for, bovine paratuberculosis in Wisconsin, J. Am. Vet. Med. Assoc., 204(4): 636-641.

35. Goodger, W.J., Collins, M.T., Nordlund, K.V., Eisele, C., Pelletier, J., Thomas, C.B. and Sockett, D.C. (1996) Epidemiologic study of on-farm management practices associated with prevalence of Mycobacterium paratuberculosis infections in dairy cattle, J. Am. Vet. Med. Assoc., 208(11): 1877-1781.

36. Obasanjo, I.O., Gröhn, Y.T. and Mohammed, H.O. (1997) Farm factors associated with the presence of Mycobacterium paratuberculosis infection in dairy herds on the New York State Paratuberculosis Control Program, Prev. Vet. Med., 32(3-4): 243-251.

37. Nielsen, S.S. and Toft, N. (2007) Assessment of management-related risk factors for paratuberculosis in Danish dairy herds using Bayesian mixture models, Prev. Vet.Med., 81(4): 306-317.

38. Widjojoatmodjo, M.N., Fluit, A.C. Torensma, R., Verdonk, G.P.H.T. and Verhoef, J. (1992) The Magnetic Immuno Polymerase Chain Reaction Assay for Direct Detection of Salmonellae in Fecal Samples, J. Clin. Microbiol., 30(12): 3195-3199.

39. Alhebabi, A.M. and Alluwaimi, A.M. (2010) Paratuberculosis in Camel (Camelus dromedarius): The Diagnostic Efficiency of ELISA and PCR, Open Vet. Sci. J., 4: $41-44$ 